\title{
Fuzzy modeling of volumetric efficiency and specific energy consumption in agricultural screw conveyors
}

\author{
Osman Özbek ${ }^{1^{*}} \mathbb{C}$ \\ $\overline{1}$ University of Selcuk, Department of Agricultural Machinery and Technologies Engineering, Alaeddin Keykubat Campus, 42075 Selcuklu, \\ Konya, Turkey. E-mail: ozbek@selcuk.edu.tr. "Corresponding author.
}

ABSTRACT: Vertical screw conveyors have low energy efficiency but this is generally acceptable within the normally low power range. Previously, a fuzzy logic approach was used to model volumetric efficiency and specific energy consumption in screw conveyors. The performance of conveyors in different working conditions and the geometry of the screw were studied. It was reported that increasing the screw speed, pitch, and loading angle also increases specific energy consumption. In this study, an intelligent fuzzy model based on the Mamdani approach was developed to predict volumetric efficiency and specific energy consumption. The model inputs included the slope, speed, and pitch of screw conveyors. The fuzzy model consists of 27 rules in which three parameters, namely the goodness of fit $(\eta)$, relative error $(\varepsilon)$, and coefficient of correlation (R), are used to evaluate the model. The goodness of fit, relative error, and coefficient of correlation values were $0.986,5.28 \%$, and 0.99 , respectively, for volumetric efficiency and 0.987, 4.93\%, and 0.99, respectively, for specific energy consumption. Results revealed that the developed model is capable of predicting volumetric efficiency and specific energy consumption in barley transport under different working conditions with high accuracy.

Key words: screw conveyors, fuzzy logic, prediction, volumetric efficiency, specific energy consumption.

\begin{abstract}
Modelagem fuzzy de eficiência volumétrica e consumo específico de energia em transportadores agrícolas de parafuso
\end{abstract}

\begin{abstract}
RESUMO: Os transportadores de parafuso verticais têm baixa eficiência energética, mas isso geralmente é aceitável dentro da faixa de potência normalmente baixa. Anteriormente, uma abordagem lógica fuzzy era usada para modelar a eficiência volumétrica e o consumo especifico de energia em transportadores de parafuso. O desempenho dos transportadores em diferentes condições de trabalho e a geometria do parafuso foram estudados. Verificou-se que aumentar a velocidade do parafuso, a inclinação e o ângulo de carga também aumenta o consumo de energia especifico. Neste estudo, um modelo fuzzy inteligente baseado na abordagem de Mamdani é desenvolvido para prever a eficiência volumétrica e o consumo especifico de energia. As entradas do modelo incluem a inclinação, velocidade e inclinação dos transportadores de parafuso. O modelo fuzzy consiste em 27 regras, nas quais três parâmetros, a saber, qualidade do ajuste ( $\eta$ ), erro relativo ( $\varepsilon$ ) e coeficiente de correlação (R), são usados para avaliar o modelo. Os valores de ajuste, erro relativo e coeficiente de correlação são de 0,986, 5,28\% e 0,99, respectivamente, para eficiência volumétrica e 0,987, 4,93\% e 0,99, respectivamente, para consumo específico de energia. Os resultados revelam que o modelo desenvolvido é capaz de prever eficiência volumétrica e consumo específico de energia no transporte de cevada sob diferentes condições de trabalho com alta precisão.
\end{abstract}

Palavras-chave: transportadores de parafuso, lógica fuzzy, previsão, eficiência volumétrica, consumo específico de energia.

\section{INTRODUCTION}

Screw conveyors are widely used for conveying a wide variety of agricultural products, mostly grain in Turkey, owing to their low price, simple design, small space requirement, negligible maintenance anddurability. They are effective for handling free-flowing or relatively free-flowing bulk solids, yielding good throughput control and providing environmentally clean solutions to handling problems. The design of screw conveyors involved a detailed consideration of the geometry of the screw and the properties of the bulk material (STEVENS, 1966; ROBERTS, 1999; FONSECA et al., 2004; OWEN \& CLEARY, 2009).
Energy consumption per unit area in agriculture is directly related to the development of farming technology and the production level (MOHAMMADI et al., 2010; AZIZI \& HEIDARI, 2013; GOKDOGAN et al., 2017).

The pitch/diameter ratio, between 0.5 and 1.2 , is the most important variable influencing the characteristics of a conveyor. The other geometrical parameters, such as the clearance between the screw and tube and the specific shaft diameter, are generally fixed by practical considerations. Furthermore, capacity was the most important operational characteristic of the conveyor and depends primarily on the specific pitch (RADEMACHER, 1981).

Soft computing technology is an interdisciplinary research field in computational 
science. Currently, soft computing-based techniques such as statistics, machine learning, neural networks, and fuzzy data analysis are being used for exploratory data analysis. In recent years, artificial intelligence methods have been used in different areas including agricultural applications. Several expert systems have been designed in the agricultural field; irrigation pumps expert system (IPES) is an expert system for the selection of irrigation pumps (ŞEFLEK \& ÇARMAN, 2003).

ZADEH (1968) proposed a fuzzy set theory in which the set boundaries were not precisely defined; however, boundaries were gradational. Fuzzy inference is the actual process of mapping from a given set of input variables to output by means of a set of fuzzy rules. The essence of modeling is to identify fuzzy rules. The four fundamental units that are necessary for the successful application of any fuzzy modeling approach are as follows: the fuzzification unit in which the input and output variables are fuzzified by considering convenient linguistic subsets such as high, medium, low, hot, warm, heavy, light, big, and small etc.; the knowledge base, which comprises the database and the rule base and provides a transition between the input and output fuzzy sets; the inference engine, which is defined as the formation of the consequent membership functions (MFs) based on the membership degrees of the premise part); and the defuzzification unit, which calculates a crisp value (ALLAHVERDI, 2002; SEN \& ALTUNKAYNAK, 2004; HASAN et al., 2013).

Fuzzy inference systems are widely used in different areas, including agricultural applications. MARAKOĞLU \& ÇARMAN (2010) developed a fuzzy knowledge-based model following the Mamdani approach that considers fuzzy modeling principles to predict soil loosening and draft efficiency in tillage. The mean relative errors of the measured and predicted values were $2.41 \%$ for soil loosening and $2.68 \%$ for draft efficiency. ÇARMAN (2008) developed a fuzzy model based on the Mamdani approach to predict changes in soil compaction due to wheel traffic. Furthermore, fuzzy logic is one of the knowledge-based techniques to address fault detection problems. ISERMANN (1998) and SCHNEIDER (1993) proposed fault detection and diagnosis approaches based on a fuzzy system. DURU et al. (2010) developed a method based on a fuzzy logic system for the evaluation of soil productivity in Turkey as well as worldwide.

HOU et al. (2010) used fuzzy comprehensive evaluation (FCE), except for traditional applications, for predicting the best watermelon cultivars. They determined that FCE could reflect the multiple characteristics of a cultivar objectively and precisely.

Ever since, many researchers applied fuzzy approaches to various engineering problems (MAMDANI, 1974; ROSS, 1995; SEN \& ALTUNKAYNAK, 2004; BARAKAT et al., 2019). However, there is no model thus far to predict volumetric efficiency and specific energy consumption depending on the structural and working characteristics of screw conveyors. Therefore, the objective of this study was to develop a fuzzy model based on the Mamdani approach for predicting volumetric efficiency and specific energy consumption in barley transport at three different slopes, speeds, and pitches of screw conveyors and then evaluate its prediction ability with the measured volumetric efficiency and specific energy consumption.

In this study, the effects of different operating conditions of screw conveyors and geometry of the screw on volumetric efficiency and specific energy consumption were investigated and experiments were conducted for this purpose. In addition, an intelligent fuzzy model based on the Mamdani approach has been developed to estimate volumetric efficiency and specific energy consumption.

\section{MATERIALS AND METHODS}

A portable screw conveyor with rubber wheels was used in this study for collecting the experimental data (Figure 1). Electric motor power of 5.5 $\mathrm{kW}$ was used to operate the machine. The electric motor was mounted to a tripod on the conveyor pipe. A belt and a pulley system were used to transfer power from the motor to the screw shaft. The angle of the conveyor was adjusted by a rope system. Table 1 displays the test unit and technical dimensions of the screw conveyor.

Barley was used as the biological material in the experiments. Barley was filled in a tank with dimensions of $1500 \times 1200 \times 800 \mathrm{~mm}$. The screw conveyor was fed by natural flow from the bottom of the tank. The moisture content and the density of barley were $10.4 \%$ and $640 \mathrm{~g} / \mathrm{L}$, respectively.

Three different screw shaft speeds (450 $\mathrm{min}^{-1}, 550 \mathrm{~min}^{-1}$ and $\left.650 \mathrm{~min}^{-1}\right)$, three different screw pitches (100 mm, $125 \mathrm{~mm}$, and $150 \mathrm{~mm}$ ) and three different loading angles $\left(15^{\circ}, 22.5^{\circ}\right.$, and $\left.30^{\circ}\right)$ were considered for the experiments. The speed of the screw shaft was adjusted by a frequency-controlled electronic variator (FKC, ATV61, $31 \mathrm{~kW}, 380 / 4$ $80 \mathrm{~V}$ HD $37 \mathrm{~N} 4)$. The screw pitch was adjusted by changing the screw shafts. Furthermore, the loading 


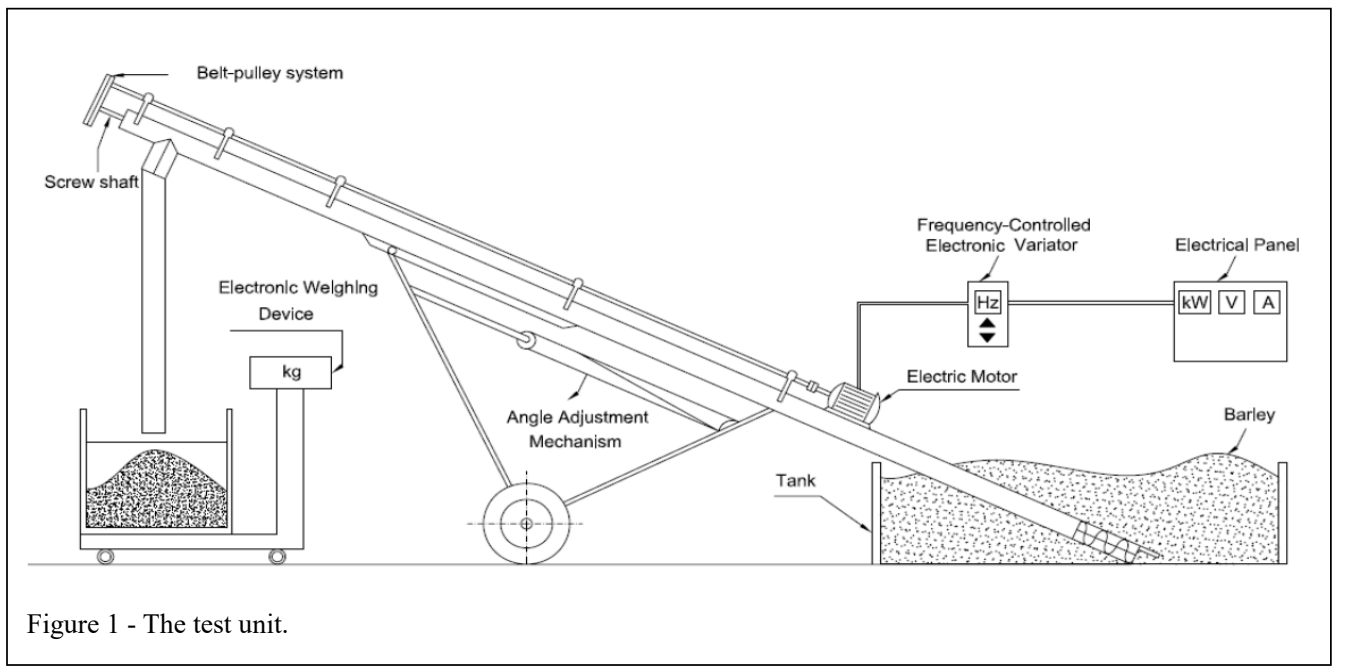

angle of the screw pipe was changed by a mechanical rope system. Each experiment was conducted with three replications.

At the end of the experiments, volumetric efficiency and specific energy consumption were determined as the output data. Volumetric efficiency was calculated by the following equation: $\eta=\frac{V_{r}}{V_{s}}$

where $\eta$ is the volumetric efficiency, $V_{r}$ is the volume of the material, which is conveyed in one rotation of the screw, and $\mathrm{V}_{\mathrm{s}}$ is the volume of the screw pitch.

$\mathrm{V}_{\mathrm{r}}$ values were calculated by the weight of the material that was conveyed in a defined time. The weight of the materials conveyed in defined times was determined using an electronic weighing device. $\mathrm{V}_{\mathrm{s}}$ values were calculated using $3 \mathrm{D}$ modeling software.

The specific energy consumption data were determined by an electrical panel with wattmeter (range: $0-50 \mathrm{~kW}$, resolution: $0.1 \mathrm{~kW}$, accuracy: \pm 0.1 ),

Table 1 - The test unit and technical dimensions of the screw conveyor.

\begin{tabular}{lc}
\hline Quantity & Dimension \\
\hline Length of the conveyor $(\mathrm{mm})$ & 8000 \\
Intake length $(\mathrm{mm})$ & 400 \\
\hline Loading angle (degree) & $15^{\circ}-22.5^{\circ}-30^{\circ}$ \\
Diameter of the screw axle (mm) & 34 \\
Diameter of the screw (mm) & 150 \\
Diameter of the pipe $(\mathrm{mm})$ & 167 \\
Pitch $(\mathrm{mm})$ & $100-125-150$ \\
\hline
\end{tabular}

ammeter (range: 0-50 A, resolution: $0.5 \mathrm{~A}$, accuracy: \pm 0.1 ) and voltmeter (range: $0-500 \mathrm{~kW}$, resolution: 1 $\mathrm{V}$, accuracy: \pm 0.1$)$.

\section{Implementation of fuzzy set theory}

A fuzzy logic toolbox from MATLAB 7.7.0

for MS Windows was used for the implementation of the fuzzy set theory into the model. For the prediction of volumetric efficiency (VE) and specific energy consumption (SEC) of the screw using the fuzzy expert system (FES), slope (SL), speed (SP), and pitch (PI) of the screw were used as the input parameters. The linguistic variables for the fuzzification of output parameters were very low (VL), low (L), low middle $(\mathrm{LM})$, middle (M), high middle (HM), high (H) and very high $(\mathrm{VH})$, and the linguistic variables of input parameters were low $(\mathrm{L})$, middle $(\mathrm{M})$, and high (H). In this study, a Mamdani max-min inference for the inference defuzzifier formula method for defuzzification was used because these operators assure a linear interpolation of the output between the rules. The triangular-shaped membership function (MFs) were used for both input and output variables because of their accuracy. The selection of the number of MFs and their initial values are based on the system knowledge and experimental conditions. The units of the used factors are PI $(\mathrm{mm}), \mathrm{SP}(1 / \mathrm{min}), \mathrm{SL}\left({ }^{\circ}\right), \mathrm{VE}$, and SEC $(\mathrm{kWh} /$ ton). Table 2 shows some of the developed fuzzy rules. Twenty-seven rules were formed. For example, Rule 4 and Rule 24 can be interpreted as follows.

Rule 4: If $\mathrm{PI}=\mathrm{L}, \mathrm{SP}=\mathrm{M}$, and $\mathrm{SL}=\mathrm{L}$, then $\mathrm{VE}=\mathrm{H}$ and $\mathrm{SEC}=\mathrm{VL}$, i.e., if the screw's PI is low, SP is middle, and SL is low, then the screw's VE is high and its SEC is very low. 
Table 2 - Fuzzy rules.

\begin{tabular}{|c|c|c|c|c|c|}
\hline \multirow[t]{2}{*}{ Rules } & \multicolumn{3}{|c|}{ 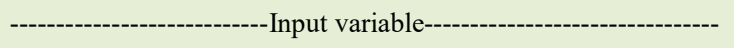 } & \multicolumn{2}{|c|}{-------------Output variables------ } \\
\hline & PI & SP & SL & VE & SEC \\
\hline Rule 1 & $\mathrm{~L}$ & $\mathrm{~L}$ & $\mathrm{~L}$ & VH & $\mathrm{L}$ \\
\hline Rule 2 & L & $\mathrm{L}$ & M & $\mathrm{H}$ & L \\
\hline .... & ..... & ...... & ..... & $\ldots \ldots$ & $\ldots \ldots$ \\
\hline Rule 27 & $\mathrm{H}$ & $\mathrm{H}$ & $\mathrm{H}$ & VL & $\mathrm{VH}$ \\
\hline
\end{tabular}

Rule 24: If $\mathrm{PI}=\mathrm{H}, \mathrm{SP}=\mathrm{M}$, and $\mathrm{SL}=\mathrm{H}$, then $\mathrm{VE}=\mathrm{VL}$ and $\mathrm{SEC}=\mathrm{VH}$, i.e., if the screw's PI is high, SP is middle, and SL is high, then the screw's VE is very low and its SEC is very high.

Fuzzification of the used factors was performed by using the following functions. The formulas were determined by using measurement values.

$$
\begin{aligned}
& P I\left(i_{1}\right)=\left\{\begin{array}{l}
i_{1} ; 100 \leq i_{1} \leq 150 \\
0 ; \text { otherwise }
\end{array}\right\} \\
& \operatorname{SP}\left(i_{2}\right)=\left\{\begin{array}{l}
i_{2} ; 450 \leq i_{2} \leq 650 \\
0 ; \text { otherwise }
\end{array}\right\} \\
& \operatorname{SL}\left(i_{3}\right)=\left\{\begin{array}{l}
i_{3} ; 15 \leq i_{3} \leq 30 \\
0 ; \text { otherwise }
\end{array}\right\} \\
& \operatorname{VE}\left(o_{1}\right)=\left\{\begin{array}{l}
o_{1} ; 0.21 \leq o_{1} \leq 0.75 \\
0 ; \text { otherwise }
\end{array}\right\} \\
& \operatorname{SEC}\left(o_{2}\right)=\left\{\begin{array}{l}
o_{2} ; 0.0435 \leq o_{2} \leq 0.141 \\
0 ; \text { otherwise }
\end{array}\right\}
\end{aligned}
$$

The memberships of the used factors were obtained from the above formulas and shown in Figure 2.

These MFs help convert numeric variables into linguistic terms. For example, the linguistic expressions and MFs of PIs obtained from the developed rules and the above formulas are as follows.

$$
\mu_{L}\left(i_{1}\right)=\left\{\begin{array}{l}
1 ; i_{1}<100 \\
\frac{125-i_{1}}{25} ; 100 \leq i_{1} \leq 125 \\
0 ; i_{1}>125
\end{array}\right\}
$$

$\mu_{L}\left(i_{1}\right)=\{1 / 100+0.9 / 102.5+\ldots+0.1 / 122.5+0 / 125\}$

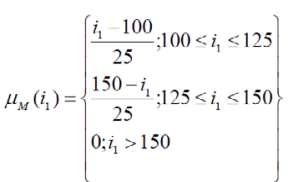

$\mu_{M}\left(i_{1}\right)=\{0 / 100+0.1 / 102.5+\ldots+1 / 125+0.9 / 127.5 \ldots+0.1 / 147.5+0 / 150\}$

$$
\mu_{H}\left(i_{1}\right)=\left\{\begin{array}{l}
0 ; i_{1}<125 \\
\frac{i_{1}-125}{25} ; \leq i_{1} \leq 150 \\
1 ; i_{1}>150
\end{array}\right\}
$$$$
\mu_{H}\left(i_{1}\right)=\{0 / 125+0.1 / 127.5+\ldots+0.9 / 147.5+1 / 150\}
$$

In the defuzzification stage, truth degrees $(\alpha)$ of the rules were determined for each rule by the aid of min, and then by taking max between working rules. For example, for $\mathrm{PI}=125 \mathrm{~mm}, \mathrm{SP}=5501 / \mathrm{min}$, and $\mathrm{SL}=25^{\circ}$, Rules 14 and 15 will be fired.

$\alpha_{14}=\min$ (Middle PI, Middle SP, Middle $\mathrm{SL})=\min (1,1,0.666)=0.666$

$\alpha_{15}=\min$ (Middle PI, Middle SP, High SL) $=\min (1,1,0.333)=0.333$

From the Mamdani max-min inference, the MF of the system is $\max \left(\alpha_{14}, \alpha_{15}\right)=0.666$. Then, the crisp output is calculated. In the defuzzification stage, the center of gravity method was used as follows (ZADEH, 1968; ÇARMAN, 2008):

$$
O^{*}=\frac{\int O \cdot \mu_{(o)} d O}{\int \mu_{(o)} d O}
$$

where $\mathrm{O}^{*}$ is the crisp value of output, $\mathrm{O}$ is the fuzzificated value, and $\mu_{(0)}$ is the membership degree of the fuzzificated value.

The predictive ability of the developed system was investigated using mathematical and statistical methods. In order to determine the relative error $(\varepsilon)$ of the system, the following equation was used (HASAN et al., 2013; ÇARMAN, 2008).

$\varepsilon=\frac{100 \%}{\mathrm{n}} \sum_{i=1}^{n}\left|\frac{y-\hat{y}}{y}\right|$

where $\mathrm{n}$ is the number of observations, $\mathrm{y}$ is the measured value, and $\hat{y}$ is the predicted value.

The relative error provides the deviation between the predicted and experimental values and should reach zero. In addition, the goodness of fit ( $\eta$ ) of the predicted system was calculated by the following equation (ÇARMAN, 2008). 

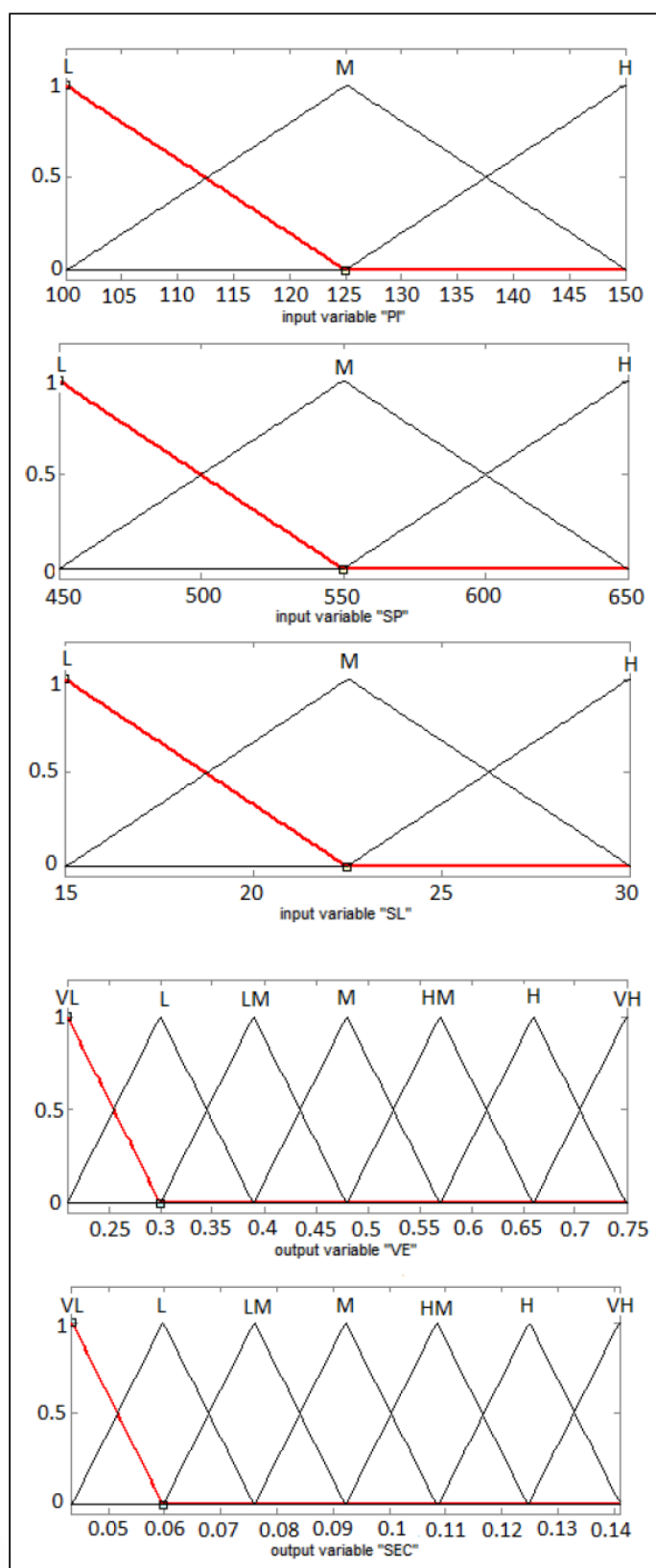

Figure 2 - The membership functions of input and output variables.

$$
\eta=\sqrt{1-\frac{\sum_{i=1}^{n}(y-\hat{y})^{2}}{\sum_{i=1}^{n}(y-\bar{y})^{2}}}
$$

where $\bar{y}$ is the mean of the measured values. The goodness of fit also demonstrates the predictive ability of the developed system and its highest value is 1 .

\section{RESULTS AND DISCUSSION}

Figure 3 showed the effect of mean of pitch, screw speed, and loading angle on specific energy consumption and volumetric efficiency. The experimental observations demonstrated that the pitch affects the capacity of the screw conveyor directly (Figure 3). An increase in pitch causes an increase in specific energy consumption and a decrease in volumetric efficiency. When the pitch increased from $100 \mathrm{~mm}$ to $125 \mathrm{~mm}$, specific energy consumption increased by approximately $6 \%$ and volumetric efficiency decreased by $40 \%$. Furthermore, when the pitch increased from $125 \mathrm{~mm}$ to $150 \mathrm{~mm}$, specific energy consumption increased by $68 \%$ and volumetric efficiency decreased by $22 \%$. YU \&ARNOLD, (1997) state that the minimum step should be less than one third of the screw diameter, and that for most materials the maximum step should consist of an approximate screw diameter.

Figure 3 shows that an increase in the screw speed causes an increase in specific energy consumption and a decrease in volumetric efficiency. When the screw speed was increased from $450 \mathrm{~min}^{-1}$ to $550 \mathrm{~min}^{-1}$, specific energy consumption increased by approximately $2 \%$ and volumetric efficiency decreased by $17 \%$. When the screw speed was increased from $550 \mathrm{~min}^{-1}$ to $650 \mathrm{~min}^{-1}$, specific energy consumption increased by $3 \%$ and volumetric efficiency decreased by $13 \%$. Increasing the rotational speed of the screw conveyor increases the power required to move particles, for a given filling level and a certain inclination angle (OWEN \& CLEARY, 2009).

The Figure 3 also shows that an increase in the loading angle causes an increase in specific energy consumption and a decrease in volumetric efficiency. When the loading angle increased from $15^{\circ}$ to $22.5^{\circ}$, specific energy consumption increased by approximately $2.5 \%$ and volumetric efficiency decreased by $12 \%$. When the loading angle increased from $22.5^{\circ}$ to $30^{\circ}$, specific energy consumption increased by $14 \%$ and volumetric efficiency decreased by $14 \%$. In case of increasing the loading angle, screws more work and it requires more energy, but this, along with the extra energy used in particle rotating movement around the screw allowed a lower axial transport (OWEN \& CLEARY, 2009).

The best operating points for volumetric efficiency were determined respectively as $0.745-$ 0,703 at $450 \mathrm{~min}^{-1}$ screw speed, $100 \mathrm{~mm}$ screw pitch and $15^{\circ}-22.5^{\circ}$ loading angles. Similarly, the best operating points for specific energy consumption were calculated respectively $0.0440 \mathrm{kWh} \mathrm{t}^{-1}$ at 550 
$\mathrm{min}^{-1}$ screw speed, $100 \mathrm{~mm}$ screw pitch, $22.5^{\circ}$ loading angles and $0.047 \mathrm{kWh} \mathrm{t}^{-1}$ at $550 \mathrm{~min}^{-1}$ screw speed, $100 \mathrm{~mm}$ screw pitch $15^{\circ}$ loading angles and $0.048 \mathrm{kWh} \mathrm{t}^{-1}$ at $550 \mathrm{~min}^{-1}$ screw speed, $125 \mathrm{~mm}$ screw pitch $22.5^{\circ}$ loading angles.

Results of the developed FES were compared with the experimental results. For volumetric efficiency, the mean values of the measured and predicted values were 0.422 and 0.413 , respectively. For specific energy consumption, the mean values of the measured and predicted values were 0.079 and $0.081 \mathrm{kWh} \mathrm{t}^{-1}$, respectively (Figure 4). Figure 4 also showed the correlation between the measured and predicted values of screw performance in different working conditions. The relationships were significant for all parameters. The correlation coefficients of relationships were determined to be 0.99 for volumetric efficiency and specific energy consumption.
The mean relative errors of the measured and predicted values were $5.28 \%$ for volumetric efficiency and $4.93 \%$ for specific energy consumption. The relative error of the predicted value was found to be less than the acceptable limits $(10 \%)$ for all parameters (TANER, 2007; MARAKOGLU \& ÇARMAN, 2010). The goodness of fit of the prediction values was determined to be 0.986 for volumetric efficiency and 0.987 for specific energy consumption. All values were close to 1.0. Similarly, LEI et.al. (2019) In their study with the fruit picking robot, they reported that the accuracy of recognition with fuzzy logic is over $90 \%$.

\section{CONCLUSION}

Increasing the screw speed, pitch, and loading angle increases specific energy consumption and decreases volumetric efficiency. Results of

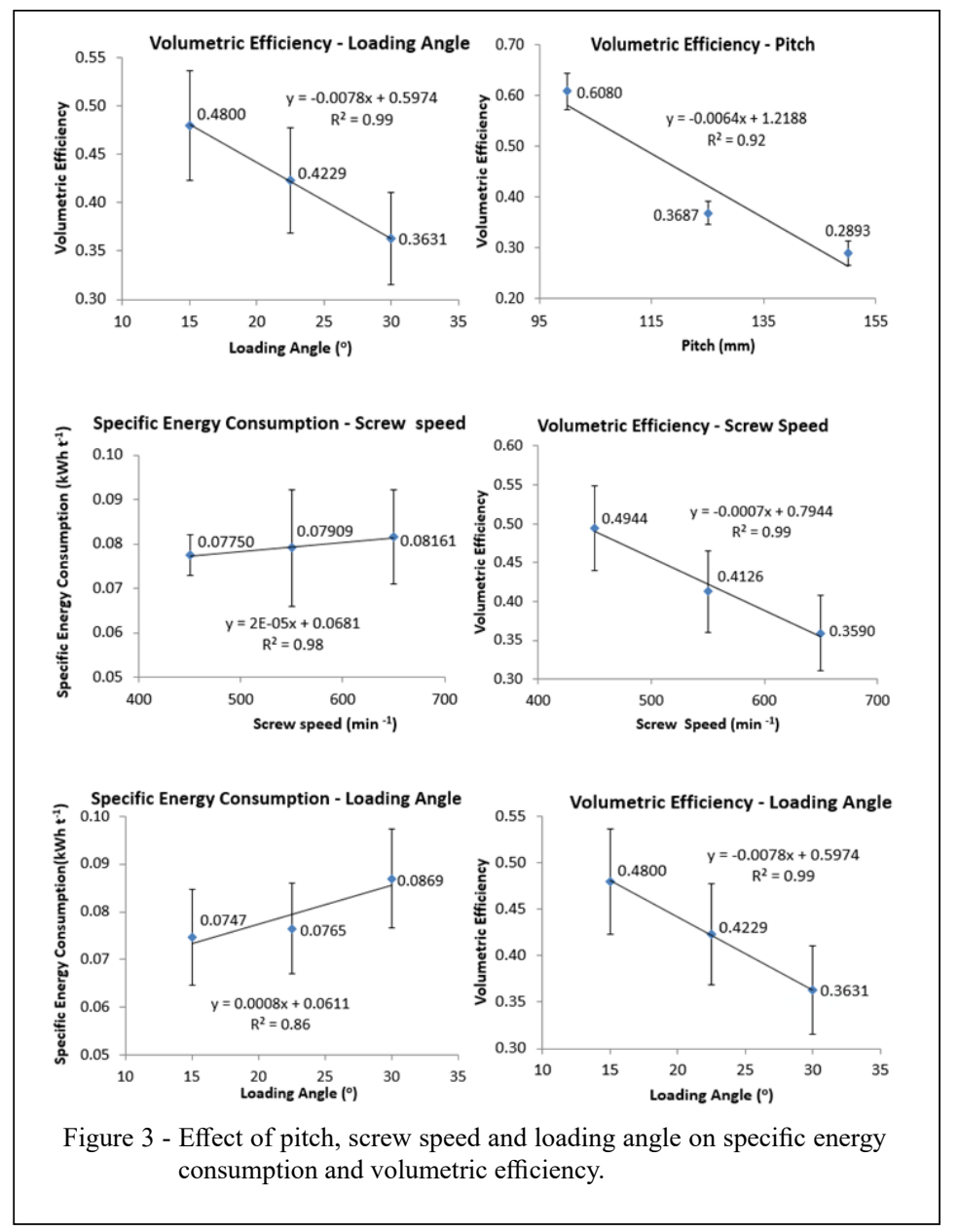

Ciência Rural, v.50, n.5, 2020. 

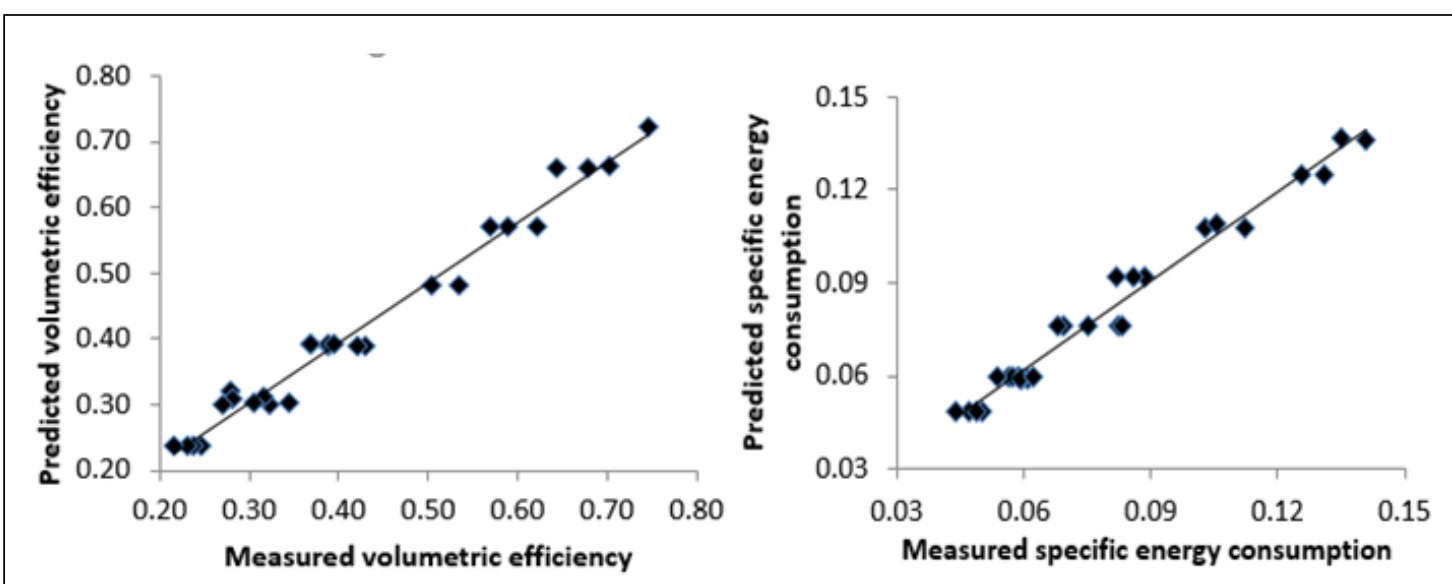

Figure 4 - Correlation between measured and predicted values of volumetric efficiency and specific energy consumption.

this study were consistent with previous granular mixing measurement techniques featuring similar experimental set-ups reported in the literature.

The best operating point for volumetric efficiency was determined as 0.745 at $450 \mathrm{~min}^{-1}$ screw speed, $100 \mathrm{~mm}$ screw pitch, $15^{\circ}$ loading angle and for specific energy consumption was calculated $0.0440 \mathrm{kWh} \mathrm{t}^{-1}$ at $550 \mathrm{~min}^{-1}$ screw speed, $100 \mathrm{~mm}$ screw pitch, $22.5^{\circ}$ loading angle.

This paper described a fuzzy model consisting of 27 rules for the prediction of volumetric efficiency and specific energy consumption in different working conditions and the geometry of the screw. The mean values of the errors for volumetric efficiency and specific energy consumption were below $6 \%$ and $5 \%$, respectively; the maximum errors for volumetric efficiency and specific energy consumption were below $13 \%$ and $12 \%$, respectively.

Therefore, these FES predicted results can be considered within acceptable limits. Results showed good agreement between the predicted and experimental values. It can be concluded that FES is an appropriate method for the prediction of volumetric efficiency and specific energy consumption in vertical screw conveyors. Furthermore, this method can help farmers find the best practice to reduce their expenditure with minimum income reduction.

\section{DECLARATION OF CONFLICT OF INTERESTS}

The authors declare no conflict of interest. The founding sponsors had no role in the design of the study; in the collection, analyses, or interpretation of data; in the writing of the manuscript, and in the decision to publish the results.

\section{ACKNOWLEDGEMENTS}

I would like to thank the Selcuk University Faculty of Agriculture, Department of Agricultural Machinery and Technologies Engineering for the facility it provided in the study.

\section{AUTHORS' CONTRIBUTIONS}

All stagesof the study were conducted by the author.

\section{REFERENCES}

ALLAHVERDI, N. Expertsystems. An artificial intelligence application. Atlas press, Istanbul, 2002.

AZIZI, A.; HEIDARI, S. A comparative study on energy balance and economical indices in irrigated and dry land barley production systems. Int. J. Environ. Sci. Technol. V.10, p1019-1028, 2013. Available from: $\quad<$ https://link.springer.com/article/10.1007\%2 Fs13762-012-0157-0>.Accessed: Mar. 22, 2019. doi: 10.1007/ s13762-012-0157-0.

BARAKAT, M.H. et al. Agricultural service mobile robot modeling and control using artificial fuzzy logic and machine vision. In: International Conference on Advanced Machine Learning Technologies and Applications. Springer, Cham, 2019. p.453-465.Available from: <https://link.springer.com/ chapter/10.1007/978-3-030-14118-9_46>. Accessed: Dec. 01, 2019. doi: 10.1007/978-3-030-14118-9_46.

ÇARMAN, K. Prediction of Soil Compaction Under Pneumatic Tires a Using Fuzzy Logic Approach. Journal of Terramechanicss v.45(4), p.103-108, 2008.Available from: <https://www. sciencedirect.com/science/article/pii/S0022489808000591>. Accessed: Aug. 12, 2018. doi: 10.1016/j.jterra.2008.10.001. 
DURU, N. et al. Soil productivity analysis based on a fuzzy logic system. Journl of the Science of Food and Agriculture, v.90(13): p.2220-2227, 2010.Available from: <https://onlinelibrary.wiley. com/doi/abs/10.1002/jsfa.4074>. Accessed: Aug. 12, 2018. doi: $10.1002 /$ jsfa. 4074 .

FONSECA, D.J. et al. A knowledge-based system for conveyor equipment selection. Expert Systems with Applications, v.26, p.615-623, 2004.Available from: <https:/www.sciencedirect. com/science/article/pii/S0957417403002197>. Accessed: Aug. 12, 2018. doi: 10.1016/j.eswa.2003.12.011.

GOKDOGAN, O. et al. Energy usage efficiency of buckwheat production in Turkey. Fresenius Environmental Bulletin, v.26(3), p.2082-2088, 2017. Available from: <https://www.prt-parlar.de/ download_feb_2017/>. Accessed: Sep. 20, 2019.

HASAN, M. et al. Rainfall Prediction Model Improvement by Fuzzy Set Theory. Journal of Water Resource and Protection, v.5, p.1-11, 2013.Available from: <https://www.scirp.org/journal/ paperinformation.aspx? paperid=26986 $>$. Accessed: Aug. 12, 2019. doi: 10.4236/jwarp.2013.51001.

HOU, P. et al. Fuzzy comprehensive evaluation for selecting mini watermelon cultivars. Journal of the Science of Food and Agriculture, v.90(6), p.938-942, 2010.Available from: <https:// onlinelibrary.wiley.com/doi/abs/10.1002/jsfa.3881>. Accessed: Nov. 14, 2018. doi: 10.1002/jsfa.3881.

ISERMANN, R. On fuzzy logic applications for automatic control, supervision and fault diagnosis. IEEE Transaction Systems, v.28, p.221-235, 1998.Available from: <https://ieeexplore. ieee.org/document/661149>. Accessed: Jun. 03, 2018. doi: $10.1109 / 3468.661149$.

MAMDANI, E.H. Application of fuzzy algorithms for simple dynamic plant. Proceedings of the IEE, v.121, p.15851588, 1974. Available from: <https://ieexplore.ieee.org/ document/5250910>. Accessed: Nov. 14, 2018. doi: 10.1049/ piee.1974.0328.

MARAKOGLU, T.; CARMAN, K. Fuzzy Knowledge-Based model for Prediction of Soil Loosenig and Draft Efficiency in Tillage. Journal of Terramechanics, v.47, p.173-178, 2010. Available from: <https://www.sciencedirect.com/science/article/ pii/S002248980900130X>. Accessed: Nov. 14, 2018. doi: 10.1016/j.jterra.2009.10.001.

MOHAMMADI, A. et al. Energy inputs-yield relationship and cost analysis of kiwifruit production in Iran. Renewable Energy, v.35, p.1071-1075, 2010. Available from: <https://www.sciencedirect.com/science/article/ pii/S0960148109003991>. Accessed: Nov. 14, 2018. doi:10.1016/j.renene.2009.09.004.
OWEN, P.J.; CLEARY, P.W. Prediction of screw conveyor performance using the Discrete Element Method (DEM). Powder Technology, v.193, p.274-288, 2009.Available from: <https:// www.sciencedirect.com/science/article/pii/S0032591009001879>. Accessed: Nov. 14, 2018. doi: 10.1016/j.powtec.2009.03.012.

ROBERTS, A.W. The influence of granular vortex motion on the volumetric performance of enclosed screw conveyors. Powder Technology, v.104, p.56-67, 1999.Available from: <https:/www. sciencedirect.com/science/article/pii/S003259109900039X>. doi:10.1016/S0032-5910(99)00039-X.

RADEMACHER, F.J.C. On possible flow back in vertical screw conveyors for cohesionless granular materials. Journal of Agricultural Engineering Research, v.26, p.225-250, 1981.Available from: <https://www.sciencedirect.com/science/ article/pii/0021863481901074>. Accessed: Dec. 26, 2018. doi: 10.1016/0021-8634(81)90107-4.

ROSS, J.T. Fuzzy logic with engineering applications. McGraw Hill Inc, New York, 1995.

SCHNEIDER, H. Implementation of a fuzzy concept for supervision and fault detection of robots. In Proceedings of the First European Congress on Fuzzy and Intelligent Technologies, v.2, p.775-780, 1993.

SEN, Z.; ALTUNKAYNAK, A. Fuzzy awakening in rainfall-runoff modeling. Nordic Hydrology, v.35(1). P.31-43, 2004. Available from: $\quad<$ https://iwaponline.com/hr/article/35/1/31/894/Fuzzyawakening-in-rainfallrunoff-modeling $>$. Accessed: Feb. 12, 2017. doi: $10.2166 / \mathrm{nh} .2004 .0003$.

STEVENS, G.N. Aspects of the Performance of Small Auger Grain Conveyors. Journal of Agricultural Engineering Research, v.11(1), p.11-18, 1966.Available from: <https://www. sciencedirect.com/science/article/pii/S0021863466800033>. Accessed: Jan. 10, 2015. doi: 10.1016/S0021-8634(66)80003-3. ŞEFLEK, A.Y.; ÇARMAN, K. An expert system project for selecting of submersible pumps. National Symposium on Mechanization in Agriculture, p.335-342, 2003. Konya/ TURKEY.

TANER, A. Design of radial centrifugal pumps using artificial neural networks. D.Sc. Thesis. Graduate School of Natural and Applied Sciences of Selcuk University, Konya/TURKEY; 2007.

YU, Y.; ARNOLD, P.C. Theoretical modelling of torque requirements for single screw feeders. Powder Technology, 93 (1997) 151-162.

ZADEH, L.A. Fuzzy algorithms. Information and Control, v.12, p.94-102, 1968.Available from: <https:/www.sciencedirect.com/ science/article/pii/S0019995868902118>. Accessed: Feb. 12, 2017. doi: 10.1016/S0019-9958(68)90211-8. 